\title{
Effect of nano-potassium fertilization on fruiting of Zaghloul date palm
}

\author{
El-Salhy A.M. ${ }^{1}$, M.M. Al-Wasfy ${ }^{2}$, E.F.M. Badawy ${ }^{1}$, F.M. Gouda ${ }^{1}$ and A.A. Shamroukh ${ }^{2 *}$ \\ ${ }^{1}$ Department of Pomology, Faculty of Agriculture, Assiut University, Assiut, Egypt \\ ${ }^{2}$ Department of Horticulture, Faculty of Agriculture, South Valley University, Qena, Egypt
}

\begin{abstract}
This investigation was conducted during the two successive seasons i.e. 2019 and 2020 on Zaghloul date palm grown at the experimental orchard, Faculty of Agriculture, South Valley University, Qena, Egypt. This work conducted to study the effect of different sources of potassium fertilizers on fruiting of Zaghloul date palm under Qena condition. Potassium fertilization via nano-technology, vinasse and potassin were used. The experiment was arranged in a complete randomized design with three replications. It is evident from the obtained results that using nano-potassium, either soil dressing or foliar spray, as well as foliar spray of vinasse or potassin significantly increased the fruit retention, bunch weight and yield/palm compared to fertilize by potassium sulphate (check treatment). Also, these treatments significantly improved dates quality in terms of increasing fruit weight, flesh percentage, TSS, sugar percentages and anthocyanin contents moreover, decreasing total acidity and total tannins compared to fertilize with the recommended potassium doses via potassium sulphate. From the results, it could be concluded that fertilized Zaghloul date palm with potassium fertilization via foliar spray of either nano-potassium, vinasse or potassium to improve the fertilization efficiency and get high yield with best dates quality. In addition, hasten advance the fruit ripening and overcome potassium fertilization problems.
\end{abstract}

Key words: Fertilization - Nano-technology, Vinasse, Date palm, Potassium, Potassin

\section{Introduction}

Date palm is considered an old common fruit tree in many countries all over the world because if could be established in a wide range of soil and environmental conditions. Egypt is the leading countries in date palm cultivation and production (FAO, 2016). It has been used as a staple food for hundreds of years in many desert areas. Dates are a rich source of sugars

*Corresponding author: A.A. Shamroukh

Email: ahmed.abdellatif@agr.svu.edu.eg

Received: December 20, 2020

Accepted: January 26, 2021

Published: January 30, 2021 and numerous minerals that are necessary for life and essentially required to support life and good health (Mertz, 1981; Wrigley, 1995 and El-Salhy et al., 2017). Fertilization is one of the important tools to increase crop yield, especial nitrogen, and potassium. Potassium fertilization is essential for fruit trees to produce an economical yield with good fruit quality (El-Salhy et al., 2017). Generally, potassium plays an important role in controlling cell water content and carbohydrate biosynthesis and mobilization in plant tissues, consequently carbohydrates play a serious role 
in vegetative growth, fruit set, yield and fruit quality (Usherwood, 1985; Meng, 1998; Rengel and Damon, 2008; Harhash and AbdelNasser, 2010 and Awad et al., 2014). Due to the lack of potassium in the market and its high price, as well as the low efficiency of its use through ground fertilization. Therefore, alternatives must be searched to fill these shortages and improve the efficiency used. Potassium shows a highly mobility and when taken up by leaves they can be rapidly distributed throughout the entire plant. Potassium foliar spray is a significant method of fertilization especially during the maturation stage since there is an intense mobilization it from leaf to fruit and $\mathrm{K}$ uptake by tree roots may be inadequate to meet the demand of this nutrient (Weinbaum et al., 1994 and Mengel and Kirkby, 2001). Foliar fertilization has the advantage of low application rates, uniform distribution of fertilizer materials and quick responses to applied nutrients (Al-Khateeb et al., 2006 and Abdalla, 2016). Also, design and development of nano fertilizers could be more soluble or more reactive than their bulk counterparts. The large surface area and small size of nano materials could allow enhancing interaction and efficient uptake of nutrients for crop fertilization. The increased surface area in nano materials can lead to increased reactivity and faster dissolution kinetics (De Rosa et al., 2010 and Mastronardi et al., 2015). The most important application of nanotechnology in agricultural crop production is

Table (1). Analysis of the tested soil.

\begin{tabular}{|c|c|c|c|}
\hline Constituents & Values & Constituents & Values \\
\hline Particle size distribution: & & Total N \% & 0.09 \\
\hline Sand $\%$ & 8.5 & P ppm (Oslen) & 3.3 \\
\hline Silt $\%$ & 21.0 & $\mathrm{~K}$ ppm (ammonium acetate) & 410.0 \\
\hline Clay $\%$ & 70.5 & \multicolumn{2}{|c|}{ Available micronutrients (EDTA, ppm): } \\
\hline Texture & Clay & $\mathrm{Fe}$ & 1.8 \\
\hline $\mathrm{pH}(1: 2.5$ extract $)$ & 8.0 & $\mathrm{Zn}$ & 2.1 \\
\hline $\mathrm{EC}(1: 2.5$ extract $) \mathrm{mmhos} / 1 \mathrm{~cm} 25^{\circ} \mathrm{cm}$ & 0.75 & Mn & 1.9 \\
\hline Organic matter $\%$ & 1.9 & $\mathrm{Cu}$ & 0.7 \\
\hline Total $\mathrm{CaCO}_{3} \%$ & 1.9 & & \\
\hline
\end{tabular}

plants gradually in a controlled manner, conversely to what occurs in the case of common fertilizers. These nano-fertilizers can be more efficient, decreasing soil pollution and other environmental risks that may occur when using chemical fertilizers (Naderi et al., 2011). Over that one of the advantages of using nanofertilizers is that application can be done in smaller amounts than when using common fertilizers (Selivanov and Zorin, 2001; Reynolds, 2002; Raikova et al., 2006; Batsmanova et al., 2013 and Subramanian et $a l ., 2015)$. The yield and fruit quality of date palm trees were greatly varied according to $\mathrm{K}$ fertilization sources and methods (Bamiftah, 2000; Ezz et al., 2010; Awad et al., 2014; Abdalla, 2016; Elsadig et al., 2017; Elsayd et al., 2018 and Al-Hajaj et al., 2020). So, the present study aimed to investigate the response of Zaghloul date palm to using nanopotassium, potassin and vinasse application.

\section{Materials and Methods}

This study was carried out during the two successive season of 2019 and 2020 on Zaghloul date palm. The palms were grown at the experimental orchard Faculty of Agriculture, South Valley University, Qena, Egypt. Some physical and chemical properties of experimental soil at $0.0-90 \mathrm{~cm}$ depth are presented in Table (1) according to the procedures of Black et al. (1965) and Carter (1993). 
Fifteen palms 25 years old, were selected under drip irrigation system, planted at $7 \times 7$ meter apart and were uniform, at similar age free of insect, damage and diseases. All the routine agro-technical operations were carried out according to the traditional schedule for date palm plantation. The leaf/bunch ratio was adjusted at the value of 8:1 for all experimental palms. All the selected Zaghloul date palms received program of fertilization consists of 10 $\mathrm{kg}$ plant compost $(2.5 \% \mathrm{~N}), 5.0 \mathrm{~kg}$ ammonium sulphate, $(20.6 \% \mathrm{~N}), 1.5 \mathrm{~kg}$ triple calcium superphosphate $\left(\begin{array}{lll}37.5 \% & \mathrm{P}_{2} \mathrm{O}_{5}\end{array}\right)$ and $1.5 \mathrm{~kg}$ potassium sulphate $\left(48 \% \mathrm{~K}_{2} \mathrm{O}\right)$ per each palm. Plant compost phosphate fertilizer were added once at the middle of January. Ammonium sulphate was splitted into three equal batches and added at the first week of March, May and July. Potassium sulphate was applied twice before pollination (last week of February) and just after fruit setting (last week of April). Other horticultural practices such as irrigation, pruning, hoeing and pest management were carried out as usual. The chosen palm trees were divided into five groups, each group contained (three trees, replicates) and received one potassium fertilization regime management as the following:

- Spraying with vinasse (2\% potassium) at $4.5 \mathrm{~L}$ per palm.

- Adding nano-potassium sulfate at $75 \mathrm{~g}$ per palm.

- Spraying with nano-potassium sulfate at $35 \mathrm{~g}$ per palm.

- Spraying with potassin $(30 \%$ potassium) at $300 \mathrm{ml}$ per palm.

- Control (applying the recommended potassium dose, $1.5 \mathrm{~kg} / \mathrm{palm}$ ).

All treatments were applied after fruit set and 30 days after fruit set. The experimental was arranged in a complete randomized block design with three replicates, one tree each. The bunches were harvested when the fruit reached full maturity and the following traits were measured.

\section{A- Yield and its components:}

\section{1- Fruit retention:}

It was calculated at harvest using the following equations:

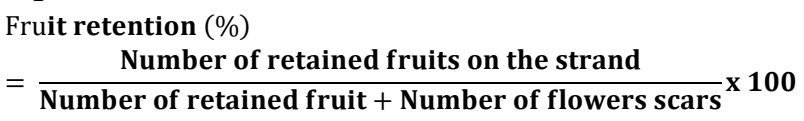

\section{Bunch weight and yield / palm:}

At the harvest time, bunches of each palm were picked and weighed, and then the yield/palm (kg) was recorded.

\section{B- Fruit characteristics:}

Sample of 50 fruits were taken randomly from each replicate to determine some physical and chemical properties of fruit as outlined in A.O.A.C. (1995).

Total Anthocyanin: content of date palm (mg/100 g fresh wt.):

Extracts were prepared by the method described by Onayemi, et al. (2006). $1 \mathrm{~g}$ skin fruit samples were pulverized with $20 \mathrm{ml}$ of $85 \%$ ethanol and $1.5 \mathrm{M} \mathrm{HCl}$ (by volume) solution. The samples were covered and kept overnight in deep freeze. The extracts were completed to $50 \mathrm{ml}$ of the solvent and then absorbance of the solution was measured at wavelength of $530 \mathrm{~nm}$, using spectrophotometer (Unico 1200-USA). Result is expressed as $\mathrm{mg} / 100 \mathrm{~g}$ of fresh fruit. Total anthocyanins were calculated using the method developed by Lees and Francis (1971). Total Anthocyanin in $\mathrm{mg} / 100 \mathrm{~g}$ fruit skin $=($ A535 $\mathrm{X}$ $\mathrm{V} \times 100) /(98.2 \times \mathrm{W})$, where $\mathrm{V}=$ total volume of extract in $\mathrm{ml}, \mathrm{W}=$ weight of fresh sample (in grams). Total soluble tannins: The percentage of tannins in the fruit was determined using the Indigo Carmen indicator according to Balbaa (1981). Titration was carried out using $0.1 \mathrm{~N}$ potassium permanganate solution. Tannins in fresh weight were calculated (as total tannins percentage) according following equation potassium permanganate $(0.1 \mathrm{~N})=0.00416 \mathrm{~g}$ 
tannins. Thereafter, the obtained data during the two seasons were collected, tabulated and subjected to the proper statistical analysis of variance method reported by Gomez and Gomez (1984) and Mead et al. (1993). The differences between treatment means were compared by Duncan's multiple range test at $5 \%$ level of probability to (Duncan 1955)

\section{Results}

\section{Yield and its components:}

Data presented in Table (2) showed the effect of different source and method of potassium fertilization on fruit retention $\%$, bunch weight and yield/palm of Zaghloul date palm during 2019 and 2020 seasons. It is obvious from the data that results took similar trend during the two studied seasons.

Such results indicated that fertilized Zaghloul date palm with potassium either via nanopotassium, vinasse or potassin was responsible to produce the highest fruit retention and consequently the heavy bunch weight and yield/palm compared to use potassium via Kmineral as potassium sulphate (check treatment). The significantly higher value of these studied yield components was recorded due to add nano- potassium sulphate (nano-K). On the contrary, the least fruit retention and lightest bunch weight and yield/palm were detected on palms that fertilized by potassium sulphate (check treatment). No significant differences were observed in such studied traits due to nano-K, vinasse or potassin used. The recorded bunch weight was (17.23, 17.14, $17.25,17.16$ and $16.42 \mathrm{~kg}$ as an av. of the two studied seasons) due to vinasse spraying nano$\mathrm{K}$ application, nano-K spraying Potassin and potassium sulphate (check treatment), respectively. The corresponding yield/palm was $(155.1,154.2,155.3,154.4$ and 147.7 $\mathrm{kg} /$ palm, respectively. Hence the increment of yield/palm was attained 5.01, 4.40, 5.15 and $4.54 \%$ as an av. two studied seasons due to vinasse spraying, nano- $\mathrm{K}$ application, nano-K spraying and potassin spraying compared to potassium sulpahte, respectively.

Therefore, it can be concluded that using both nano-K, potassin or vinasse was the best tool to produce heavy bunch weight and consequently high yield/palm.

\section{Fruit quality:}

Date presented in Tables (3, 4 and 5) showed the effect of nano-K, vinasse and potassin application on fruit quality of Zaghloul date palm during 2019 and 2020 seasons. It is obvious from the obtained data that the results took similar trend during the two studied seasons.

It is evident from prementioned data that using either nano-K, vinasse or potassin significantly improved fruit quality in terms of increasing fruit weight, dimension, flesh percentage, TSS and sugar and anthocyanin contents and decreasing total acidity and total tannins compared to fertilize by the recommended doses of potassium via potassium sulphate (check treatment).

Using nano-K gave the maximum values of physical fruit properties compared to fertilize by potassium sulphate (check treatment). On other hand, the least values of physical fruit traits were recorded due to check treatment.

The obtained fruit weight was (15.6, 15.2, 15.6, 15.4 and $14.6 \mathrm{~g}$ as an av. of the two studied seasons due to vinasse spraying (T1), nano-K application (T2), nano-K spraying (T3), potassin spraying (T4) and check treatment (T5), respectively. Hence, the increment percentage of fruit weight attained $6.85,4.11,6.85$ and $5.48 \%$ due to T1, T2, T3 and T4 compared to check treatment (T5), respectively. Moreover, potassin spraying gave the maximum values of chemical fruit juice contents compared to check treatment. In the opposite, the lowest values recorded due to fertilize with potassium sulphate (check treatment). The recorded total soluble solids values were $(32.3,33.9,33.7,34.1$ and $31.2 \%)$, 
as well as anthocyanin contents (35.0, 37.0, $37.7,38.5$ and $30.0 \mathrm{mg} / 100 \mathrm{~g}$ as an av. of the two studied seasons) due to use T1, T2, T3, T4 and $\mathrm{T} 5$, respectively. Thus, the corresponding increment percentage of TSS were 3.52, 8.65, 8.01 and $9.29 \%$ as well as of anthocyanin contents were $16.67,23.33,25.67$ and $28.33 \%$ due to T1, T2, T3 and T4 compared T5, respectively. On other hand, the highest values of total acidity $\%$ and tannins $\%$ recorded on fruit from checked palm that fertilized with recommended potassium via potassium sulphate, whereas the lowest values recorded on dates that harvest from sprayed with potassin. The recorded tannin percentage was $(0.494,0.470,0.475,0.463$ and $0.578 \%$ as an av. of the two studied seasons) due to T1 to T5, respectively. Hence, the corresponding decrement percentage of tannins were 14.53, $18.69,17.82$ and $19.90 \%$ due to vinasse spraying, nano-K application, nano-K spraying and potassin spraying compared to check treatment, respectively. Moreover, no significant differences in fruit quality were found due to use vinasse, nano-K or potassin. In a general, view the abovementioned results disclosed that used nano-potassium or vinasse as well as potassium greatly improved bunch weight and yield/palm. In addition, such treatments improved the fruit quality in terms of increasing fruit weight, total soluble solids and sugar and anthocyanin contents and decreasing total tannins, hence advanced the ripening and harvesting date.

These effects are very important in dates production since the improvement in dates quality is the most important target that induce an increase in packable yield and price.

Table 2. Effect of vinasse, nano-potassium and potassin on fruit retention, bunch weight and yield/palm of Zaghloul date palm during 2019 and 2020 seasons.

\begin{tabular}{|c|c|c|c|c|c|c|c|c|c|}
\hline \multirow{2}{*}{$\begin{array}{c}\text { Character } \\
\text { Treat. }\end{array}$} & \multicolumn{3}{|c|}{ Fruit retention \% } & \multicolumn{3}{|c|}{ Bunch weight (kg) } & \multicolumn{3}{|c|}{ Yield/palm (kg) } \\
\hline & 2019 & 2020 & Mean & 2019 & 2020 & Mean & 2019 & 2020 & Mean \\
\hline $\begin{array}{l}\text { Vinasse spraying } \\
\text { (T1) }\end{array}$ & $49.85^{\mathrm{A}}$ & $51.33^{\text {В }}$ & 50.59 & $17.35^{\mathrm{AB}}$ & $17.70^{\mathrm{A}}$ & 17.23 & $156.2^{\mathrm{A}}$ & $153.9^{\mathrm{A}}$ & 155.1 \\
\hline $\begin{array}{l}\text { Nano-K application } \\
\text { (T2) }\end{array}$ & $50.38^{\mathrm{A}}$ & $52.11^{\mathrm{A}}$ & 51.26 & $17.50^{\mathrm{A}}$ & $16.77^{\mathrm{A}}$ & 17.14 & $157.5^{\mathrm{A}}$ & $150.9^{\mathrm{A}}$ & 154.2 \\
\hline $\begin{array}{l}\text { Nano-K spraying } \\
\text { (T3) }\end{array}$ & $49.56^{\mathrm{A}}$ & $51.18^{\mathrm{A}}$ & 50.37 & $17.60^{\mathrm{A}}$ & $16.90^{\mathrm{A}}$ & 17.25 & $158.4^{\mathrm{A}}$ & $152.1^{\mathrm{A}}$ & 155.3 \\
\hline $\begin{array}{l}\text { Potassin spraying } \\
\text { (T4) }\end{array}$ & $49.98^{\mathrm{A}}$ & $51.56^{\mathrm{A}}$ & 50.77 & $17.38^{\mathrm{AB}}$ & $16.93^{\mathrm{A}}$ & 17.16 & $156.4^{\mathrm{A}}$ & $152.4^{\mathrm{A}}$ & 154.4 \\
\hline $\begin{array}{l}\mathrm{K}_{2} \mathrm{SO}_{4} \text { (Control) } \\
\text { (T5) }\end{array}$ & $46.80^{\mathrm{B}}$ & $48.32^{\mathrm{B}}$ & 47.56 & $16.85^{\mathrm{B}}$ & $16.10^{\mathrm{B}}$ & 16.42 & $151.3^{\mathrm{B}}$ & $144.0^{\mathrm{B}}$ & 147.7 \\
\hline LS.D. $5 \%$ & 2.61 & 2.78 & & 0.53 & 0.55 & & 4.83 & 5.12 & \\
\hline
\end{tabular}

Means with different letters are significantly different at $\mathrm{p}<0.05$

Table 3. Effect of vinasse, nano-potassium and potassin on fruit weight, flesh \%, fruit length and fruit diameter of Zaghloul date palm during 2019 and 2020 seasons.

\begin{tabular}{|c|c|c|c|c|c|c|c|c|c|c|c|c|}
\hline \multirow{2}{*}{$\begin{array}{l}\text { Charac. } \\
\text { Treat. }\end{array}$} & \multicolumn{3}{|c|}{ Fruit weight (g) } & \multicolumn{3}{|c|}{ Flesh \% } & \multicolumn{3}{|c|}{ Fruit length (cm) } & \multicolumn{3}{|c|}{ Fruit diameter } \\
\hline & 2019 & 2020 & Mean & 2019 & 2020 & Mean & 2019 & 2020 & Mean & 2019 & 2020 & Mean \\
\hline T1 & $15.2^{\mathrm{B}}$ & $16.0^{\mathrm{A}}$ & 15.6 & $89.8^{\mathrm{A}}$ & $89.2^{\mathrm{A}}$ & 89.5 & $4.71^{\mathrm{A}}$ & $4.81^{\mathrm{A}}$ & 4.76 & $2.31^{\mathrm{A}}$ & $2.36^{\mathrm{A}}$ & 2.34 \\
\hline $\mathbf{T} 2$ & $14.8^{\mathrm{A}}$ & $15.6^{\mathrm{A}}$ & 15.2 & $89.2^{\mathrm{AB}}$ & $88.9^{\mathrm{A}}$ & 89.1 & $4.64^{\mathrm{AB}}$ & $4.75^{\mathrm{A}}$ & 4.70 & $2.28^{\mathrm{AB}}$ & $2.33^{\mathrm{AB}}$ & 2.31 \\
\hline T3 & $15.2^{\mathrm{A}}$ & $16.0^{\mathrm{A}}$ & 15.6 & $89.8^{\mathrm{A}}$ & $89.5^{\mathrm{A}}$ & 89.7 & $4.69^{\mathrm{A}}$ & $4.80^{\mathrm{A}}$ & 4.75 & $2.30^{\mathrm{AB}}$ & $2.35^{\mathrm{A}}$ & 2.33 \\
\hline T4 & $15.0^{\mathrm{A}}$ & $15.8^{\mathrm{A}}$ & 15.4 & $89.3^{\mathrm{AB}}$ & $89.1^{\mathrm{A}}$ & 89.2 & $4.64^{\mathrm{AB}}$ & $4.75^{\mathrm{A}}$ & 4.70 & $2.28^{\mathrm{AB}}$ & $2.32^{\mathrm{AB}}$ & 34.1 \\
\hline T5 & $14.2^{\mathrm{B}}$ & $14.9^{\mathrm{B}}$ & 14.6 & $87.1^{\mathrm{B}}$ & $86.4^{\mathrm{B}}$ & 86.8 & $4.52^{\mathrm{B}}$ & $4.61^{\mathrm{B}}$ & 4.57 & $2.23^{\mathrm{B}}$ & $2.27^{\mathrm{B}}$ & 2.25 \\
\hline LS.D. 5\% & 0.55 & 0.52 & & 2.38 & 2.43 & & 0.14 & 0.13 & & 0.07 & 0.07 & \\
\hline
\end{tabular}

Means with different letters are significantly different at $\mathrm{p}<0.05$ 
Table 4. Effect of vinasse, nano-potassium and potassin on TSS, Red. sugar \%, No. Red. sugar $\%$ and Total sugar \% of Zaghloul date palm during 2019 and 2020 seasons.

\begin{tabular}{|c|c|c|c|c|c|c|c|c|c|c|c|c|}
\hline \multirow{2}{*}{$\begin{array}{l}\text { Charac. } \\
\text { Treat. }\end{array}$} & \multirow{2}{*}{$\begin{array}{l}\text { TSS \% } \\
2019\end{array}$} & \multirow{2}{*}{2020} & \multirow[b]{2}{*}{$\begin{array}{l}\text { Mea } \\
\mathrm{n}\end{array}$} & \multicolumn{3}{|c|}{ Red. sugar \% } & \multicolumn{3}{|c|}{ No. Red. sugar \% } & \multicolumn{3}{|c|}{ Total sugar \% } \\
\hline & & & & 2019 & 2020 & $\begin{array}{l}\text { Mea } \\
\text { n }\end{array}$ & 2019 & 2020 & $\begin{array}{l}\text { Mea } \\
\text { n }\end{array}$ & 2019 & 2020 & $\begin{array}{l}\text { Mea } \\
\text { n }\end{array}$ \\
\hline T1 & $\begin{array}{l}32.7 \\
\text { B }\end{array}$ & $31.8^{\mathrm{B}}$ & 32.3 & $14.6^{\mathrm{B}}$ & $14.0^{\mathrm{B}}$ & 14.3 & $9.7^{\text {B }}$ & $9.5^{\mathrm{B}}$ & 9.6 & $24.3^{\text {B }}$ & $23.5^{\mathrm{B}}$ & 23.9 \\
\hline $\mathbf{T} 2$ & $34.3^{\mathrm{A}}$ & $\begin{array}{l}33.4 \\
\text { A }\end{array}$ & 33.9 & $\begin{array}{l}15.2 \\
\mathrm{~A}\end{array}$ & $\begin{array}{l}14.5 \\
A^{14}\end{array}$ & 14.9 & ${ }_{\mathrm{A}}^{10.3}$ & $10.1^{\mathrm{A}}$ & 10.2 & $\begin{array}{l}25.5 \\
\mathrm{~A}\end{array}$ & $\begin{array}{l}24.6 \\
\mathrm{~A}\end{array}$ & 25.1 \\
\hline $\mathbf{T 3}$ & $\begin{array}{l}34.1 \\
\text { A }\end{array}$ & $33.2^{\mathrm{A}}$ & 33.7 & $\begin{array}{l}15.1 \\
\mathrm{~A}\end{array}$ & $\begin{array}{l}14.5 \\
A^{14}\end{array}$ & 14.8 & ${ }_{\mathrm{A}}^{10.2}$ & $10.0^{\mathrm{A}}$ & 10.1 & $\begin{array}{l}25.3 \\
A\end{array}$ & $\begin{array}{l}24.5 \\
\text { A }\end{array}$ & 24.9 \\
\hline $\mathbf{T 4}$ & $\begin{array}{l}34.5 \\
\mathrm{~A}\end{array}$ & $33.6^{\mathrm{A}}$ & 34.1 & $\begin{array}{l}15.3 \\
A\end{array}$ & $\begin{array}{l}14.7 \\
\mathrm{~A}\end{array}$ & 15.0 & ${ }_{\mathrm{A}}^{10.3}$ & $10.0^{\mathrm{A}}$ & 10.2 & $\begin{array}{l}25.6 \\
\mathrm{~A}\end{array}$ & $\begin{array}{l}24.7 \\
\mathrm{~A}\end{array}$ & 25.2 \\
\hline T5 & $31.6^{\mathrm{C}}$ & $30.8^{\mathrm{C}}$ & 31.2 & $14.1^{\mathrm{B}}$ & $13.3^{\mathrm{C}}$ & 13.7 & $9.4^{\mathrm{C}}$ & $9.4^{\mathrm{B}}$ & 9.4 & $23.5^{\mathrm{C}}$ & $22.7^{\mathrm{C}}$ & 23.1 \\
\hline LS.D. 5\% & 0.98 & 0.91 & & 0.46 & 0.39 & & 0.29 & 0.26 & & 0.65 & 0.68 & \\
\hline
\end{tabular}

Means with different letters are significantly different at $\mathrm{p}<0.05$

Table 5. Effect of vinasse, nano-potassium and potassin on anthocyanin, acidity and tannin percentage of Zaghloul date palm during 2019 and 2020 seasons.

\begin{tabular}{|c|c|c|c|c|c|c|c|c|c|}
\hline \multirow{2}{*}{$\begin{array}{l}\text { Charac. } \\
\text { Treat. }\end{array}$} & \multicolumn{2}{|c|}{ Anthocyanin } & \multirow[b]{2}{*}{ Mean } & \multicolumn{2}{|l|}{ Acidity } & \multirow[b]{2}{*}{ Mean } & \multicolumn{2}{|c|}{ Tannin \% } & \multirow[b]{2}{*}{ Mean } \\
\hline & 2019 & 2020 & & 2019 & 2020 & & 2019 & 2020 & \\
\hline T1 & $33.4^{\mathrm{B}}$ & $36.6^{\mathrm{B}}$ & 35.0 & $0.207^{\mathrm{B}}$ & $0.215^{\mathrm{B}}$ & 0.211 & $0.478^{\mathrm{B}}$ & $0.510^{\mathrm{B}}$ & 0.494 \\
\hline $\mathbf{T 2}$ & $33.5^{\mathrm{A}}$ & $38.4^{\mathrm{A}}$ & 37.0 & $0.198^{\mathrm{B}}$ & $\begin{array}{l}0.204 \\
B C\end{array}$ & 0.201 & $0.455^{\mathrm{B}}$ & $0.484^{\mathrm{B}}$ & 0.470 \\
\hline T3 & $36.1^{\mathrm{A}}$ & $39.2^{\mathrm{A}}$ & 37.7 & $0.200^{\mathrm{B}}$ & $\begin{array}{l}0.206 \\
\text { BC }\end{array}$ & 0.203 & $0.460^{\mathrm{B}}$ & $0.489^{\mathrm{B}}$ & 0.475 \\
\hline T4 & $36.9^{\mathrm{A}}$ & $40.1^{\mathrm{A}}$ & 38.5 & $0.193^{\text {в }}$ & $0.198^{\mathrm{C}}$ & 0.196 & $0.445^{\text {в }}$ & $0.480^{\mathrm{B}}$ & 0.463 \\
\hline T5 & $28.6^{\mathrm{C}}$ & $31.4^{\mathrm{C}}$ & 30.0 & $0.231^{\mathrm{A}}$ & $0.246^{\mathrm{A}}$ & 0.239 & $0.544^{\mathrm{A}}$ & $0.611^{\mathrm{A}}$ & 0.578 \\
\hline LS.D. 5\% & 1.82 & 2.18 & & 0.016 & 0.013 & & 0.023 & 0.031 & \\
\hline
\end{tabular}

\section{Discussion}

Potassium is important in the formation and function of proteins, fats, carbohydrates and chlorophyll and in maintaining the balance of salts and water in plant cell (Marschner, 1995). Potassium activates many different enzymes involved in plant growth and vigor improves qualitative aspects of production such as colour, taste, consistency and preservation of many fruits (Dhillon et al., 1999).

Nano-technology deals with particles measuring a dimension of one-billionth of a meter or one-millionth of a millimeter.
Nano-fertilizers are nutrient carriers of nanodimensions ranging from 30 to $40 \mathrm{~nm}\left(10^{-9}\right.$ $\mathrm{m}$ or one-billionth of a meter). Nanofertilizers intended to improve the nutrient use efficiencies by exploiting unique properties of nano-particles. The nanofertilizers are synthesized by fortifying nutrients singly or in combinations onto the adsorbents with nano-dimension. Both physical (top-down) and chemical (bottomup) approaches are used to produce nanomaterials, and the targeted nutrients are loaded as it is for cationic nutrients $\left(\mathrm{NH}_{4}{ }^{+}\right.$, $\mathrm{K}^{+}, \mathrm{Ca}^{2+}, \mathrm{Mg}^{2+}$ ) and after surface modification for anionic nutrients $\left(\mathrm{NO}_{3}\right.$, 
$\mathrm{PO}_{42}, \mathrm{SO}_{42}$ ). Nano-fertilizers are known to release nutrients slowly and steadily for more than 30 days which may assist in improving the nutrient use efficiency without any associated ill-effects. Since the nano-fertilizers are designed to deliver slowly over a long period of time, the loss of nutrients is substantially reduced vis-à-vis environmental safety (Subramanian et al., 2015). Vinasse as a sugarcane distillery wastes, has been used as soil amendment, since it contain important amounts of plant nutrients and organic matter. Vinasse contains high levels of organic matter, potassium, calcium and moderate amounts of nitrogen and phosphorus. Application of vinasse is a common practice in sugarcane cultivated areas and can fully substitute $\mathrm{K}$ and partially $\mathrm{P}$ on crops fertilization (Gomez and Rodriguez, 2000). The promotive effect of potassium fertilization on growth, nutrient status and fruiting of date palm were emphasized by Bamiftah, 2000; Ezz et al., 2010; Harhash and Abdel-Nasser, 2010; AlObeed et al., 2013; Awad et al., 2014; ElSadig et al., 2017; Elsayed et al., 2018 and Al-Hajaj et al., 2020. They concluded that using different forms of potassium fertilization had a positive effect on fruit set and yield as well as fruit quality.

\section{Conclusion}

On the light of the previous results, it could be recommended that fertilized Zaghloul date palm with potassium fertilization via either vinasse or potassin spraying as well as nano-potassium to get high yield with best fruit quality. In addition, hasten advance the fruit ripening.

\section{References}

A.O.A.C. (1995) 'Association of Official analytical chemists. Official methods of analysis, 16 ${ }^{\text {th }}$ Ed.' AOAC International, Washington, D.C., USA.
Abdalla, M.G. (2016) 'Effect of horticultural practices on fruiting of some date palm cultivars under Assiut conditions.' Ph.D. Thesis, Fac. Agric., Assiut Univ., 164 p.

Al-Hajaj, H. S., J. Y. Ayad, Y. A. Othman and A. Abu-Rayyan (2020) 'Foliar potassium application mproves fruit yield and quolity of 'MEDJOOL'datepalm.' Fresenius enviromental al bullutin 29(3): 14361442.

Al-Khateeb, A.A.; A.M. Al-Jabr and A.M. Al-Jabr (2006) 'Date Palm in Saudi Arabia.' Date Palm Research Center, Ministry of Agriculture, Al-Hassa, Saudi Arabia 138p.

Al-Obeed, R., H. Kassem and M. Ahmed (2013) 'Effect of levels and methods of potassium and phosphorus fertilization on yield, fruit quality and chemical composition of "Khalas" date palm cultivar.' Life Science Journal 10(4): 1111-1118.

Awad, M. A., S. M. Ismail and A. D. AlQurashi (2014) 'Effect of potassium soil and foliar spray fertilization on yield, fruit quality and nutrient uptake of 'Seweda' date palm grown in sandy loam soil.'Journal of Food, Agriculture \& Environment 12(1): 305-311.

Balbaa, S.L. (1981) 'Chemistry of drugs. laboratory manual.' Cairo Univ., Chapter 6: 127-132.

Bamiftah, M. (2000) 'Effect of potassium fertilization and bunch thinning on the yield and the annual of leaves and flower clusters of Zaghloul date palms.' Res. Report. Horticulture Section, Agricultural Research Center, Hadramout Governorate, Yemen, 15: 134-141.

Batsmanova, L., L. Gonchar, N. Y. Taran and A. Okanenko (2013) 'Using a colloidal solution of metal nanoparticles 
as micronutrient fertiliser for cereals, Sumy State University.'

Black, G.A.; D.D. Evans; L.E. Ersminger; J.L. White and F.E. Dark (1965) 'Methods of soil analysis.' Amer. Soc. Agron. Inc. Bull. Madison, Wisconsin, USA, 891-1400.

Carter, M.R. (1993)'Soil sampling and methods analysis.' Canadian Soc. Soil Sci. Lewis Publishers, London, Tokyo, ISBN-100873718615.

DeRosa, M. C., C. Monreal, M. Schnitzer, R. Walsh and Y. Sultan (2010)'Nanotechnology in fertilizers.' Nature nanotechnology 5(2): 91.

Dhillon, W.S.; A.S. Bindra and B.S. Brar (1999). 'Response of grapes to potassium fertilization in relation to fruit yield, quality, and petiole nutrient status.' J. of Indian Society of Soil Sci., 47 (1): 89-94.

Elsadig, E. H., H. J. Aljuburi, A. H. B. Elamin and M. O .Gafar (2017) 'Impact of organic manure and combination of NPKS, on yield, fruit quality and fruit mineral content of Khenazi date palm (Phoenix dactylifera L.) cultivar.' Journal of Scientific Agriculture: 335-346.

El-Salhy, A.M.; Eman A.A. Abou-Zaid; Y.M.S. Diab and Heba A.M. Mohamed (2017) 'Effect of Antioxidants, Growth Regulators and Yeast Spraying on Fruiting of Seewy Date Palms.' Assiut J. Agric. Sci., 48 (5): 178-186.

Elsayd, I. E.-R., S. El-Merghany and E. Zaen El-Dean(2018)'Influence of Potassium Fertilization on Barhee Date Palms Growth, Yield and Fruit Quality Under Heat Stress Conditions.' Journal of Plant Production 9(1): 73-80.

Ezz, T., H. Kassem and H. Marzouk (2010) ' Response of Date Palm Trees to Different Nitrogen and Potassium Application Rates.' IV International Date Palm Conference 882:761-768.
FAO (2016) 'Quarterly Bulletin of Statistics' 6 No. 113-32 yearbook Annual 12 Prod. 48: 155-157.

Gomez, J. and O. Rodriguez (2000) 'Effect of vinasse on sugar cane productivity.' Rev. Fac. Agron. (Luz) 17: 318-326.

Gomez, K.A. and A.A. Gomez (1984) ' Statistical Procedures for Agriculture Research, John Wiley and Sons, New York,'130p.

Harhash, M. and G. Abdel-Nasser (2010) ' Improving of fruit set, yield and fruit quality of "Khalas" tissue culture derived date palm through bunches spraying with potassium and/or boron.' Australian Journal of Basic and Applied Sciences, 4 (9): 1519-1531.

Lees, D., and F. Francis (1971) 'Quantitative methods for anthocyanins: 6. Flavanols and Anthocyanins in Cranberries'. Journal of Food Sciences, 36 (7): 10561060.

Marschner, H. (1995) 'Mineral nutrition of higher plants. Second Ed.' Academic Press-London 989p.

Mastronardi, E., P .Tsae, X. Zhang, C. Monreal and M. C. DeRosa (2015) 'Strategic role of nanotechnology in fertilizers: potential and limitations.' Nanotechnologies in food and agriculture, Springer,Berlin: 25-67.

Mead, R.; R.N. Gurnow and A.M. Harted (1993) 'Statistical Methods in Agriculture and Experimental Biology ( $2^{\text {nd }}$ ed.) ' Chapman and Hall, London, 1044.

Meng, A. (1998) 'Experiment of applying bio potassium fertilizer for Shatianyou Pomella variety.' South China fruits. 27 (6): 22-27.

Mengel, K., 2001. 'Alternative or complementary role of foliar supply in mineral nutrition' In International Symposium on Foliar Nutrition of Perennial Fruit Plants 594 (pp. 33-47). 
Mengel, K. And E.A. Kirkby (2001) ' Principles of Plant Nutrition. ' $5^{\text {th }}$ rev. ed, Kluwer Academic Publishers (United States), ISBN-10:1402000081.

Mertz, W. (1981) 'The essential trace elements.' Science, 213, Issue 4514: 1332-1338.

Naderi, M., A. Danesh Shahraki and R. Naderi (2011) 'Application of nanotechnology in the optimization of formulation of chemical fertilizers.' Iranian Journal of Nanotechnology 12: 16-23.

Onayemi, O.O., Neto, C.C. and Heuvel, J.E.V., (2006) 'The effect of partial defoliation on vine carbohydrate concentration and flavonoid production in cranberries.' HortScience, 41(3), pp.607-611.

Raikova, O.P., Panichkin, L.A. and Raikova, N.N., (2006)'Studies on the effect of ultrafine metal powders produced by different methods on plant growth and development.' Nanotechnologies and information technologies in the $21 \mathrm{st}$ century. In Proceedings of the International Scientific and Practical Conference (pp. 108-111).

Rengel, Z. and P.M. Damon (2008) 'Crops and genotypes differ in efficiency of potassium uptake and use.' Physiologia Plantarum, 133 (4): 624-636.

Reynolds, G.H. (2002) 'Forward to the future: Nano-technology and regulatory policy.' Pacific Research Institute.

Selivanov, V. and E. Zorin (2001) 'Sustained action of ultrafine metal powders on seeds of grain crops.' Perspekt. Materialy, 4: 66-69.

Subramanian, K. S., A. Manikandan, M. Thirunavukkarasu and C. S Rahale (2015) 'Nano-fertilizers for balanced crop nutrition.' Nanotechnologies in food and agriculture, Springer: 69-80.

Usherwood, N.R. (1985) 'The role of potassium in crop quality.' Potassium in agriculture, 389-513.

Weinbaum, S., F. Niederholzer, S. Ponchner, R. Rosecrance, R. Carlson, A. Whittlesey and T. Muraoka (1994) ' Nutrient uptake by cropping and defruited field-grownFrench'prune trees.' Journal of the American Society for Horticultural Science 119 (5): 925-930.

Wrigley, G. (1995) 'Date palm (Phoenix dactylifera L.) '(Palmae) 399-403. In: J. Smartt and N.W. Simmonds (eds). Evolution of Crop Plants $2^{\text {nd }}$ edition, Longman, U.K.: 399-403. 